Journal of Educational Research in Developing Areas (JEREDA)

Vol. 2. Issue 1, Pp. 34-51, 2021

http://www.jeredajournal.com

E-mail: info@jeredajournal.com

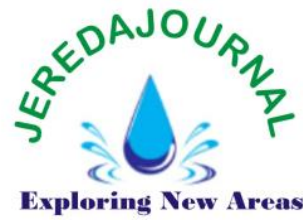

Research Article DOI: https://doi.org/10.47434/JEREDA.

eISSN: $2735-9107$

\title{
ENROLMENT PATTERNS IN FEDERAL UNIVERSITIES BASED ON THREE CRITERIA (2010-2031): A TIME SERIES ANALYSIS
}

\author{
*Valentine Joseph Owan ${ }^{1}$, Eyiene Ameh², Mary Chinelo Ubabudu ${ }^{3}$ \\ 1,2Department of Educational Management, University of Calabar, Nigeria \\ ${ }^{2}$ Department of Educational Management, University of Calabar, Nigeria \\ ${ }^{3}$ Department of Business Administration, Airforce Institute of Technology, Kaduna, \\ Nigeria ${ }^{1}$ owanvalentine@gmail.com; ${ }^{2}$ eyiency@yahoo.com; ${ }^{3}$ cubabudu@yahoo.com
}

*Corresponding author: 1 owanvalentine@gmail.com

(10) https://orcid.org/0000-0001-5715-3428

Received: $15^{\text {th }}$ March, 2021; Revised:22 ${ }^{\text {nd }}$ March, 2021; Accepted: $3^{\text {rd }}$ April, 2021

\begin{abstract}
Introduction: There is a general agreement among previous studies that gender, merit and catchment area criteria allows for access to university education, but the pattern of these variables over the years has not been proven in these studies.

Purpose: This study used a times series approach to evaluate the enrolment patterns in federally owned universities in South-South Zone, Nigeria, based on the gender, merit and catchment area criteria.
\end{abstract}

Methodology: The descriptive survey design was adopted for this study. A purposive sampling technique was adopted to choose three universities based on the generation of their establishment. The evaluation covered from 2010 to 2019 using stationary time-bound data collected from the academic planning units of the institutions through a checklist. Future enrolment forecasts were made to 2031 using the moving average forecasting technique.

Results: A gender-based difference in enrolment, in favour of males was recorded between 2010 and 2019; there were notable fluctuations in the enrolment pattern based on the merit criterion from 2010 to 2019; the enrolment pattern in terms of the catchment area criterion was consistent from 2010 - 2019. In terms of the projection, it was predicted that enrolment at the aggregate level would rise continuously across federal universities, but not at the institutional level. more women than men are expected to be enrolled in academic programmes at federal institutions, while at the institutional level, gender-based enrolment can fluctuate.

Recommendations/Classroom Implications: Based on these findings, implications are discussed for future enrolment decisions at both the institutional and national levels.

Keywords: Admission, catchment area, forecast, gender, higher education, merit

Cite paper as:

Owan, V. J., Ameh, E., \& Ubabudu, M. C. (2021). Enrolment patterns in federal universities based on three criteria (2010-2031): A time series approach. Journal of Educational Research in Developing Areas, 2 (1), 34-51. https://doi.org/10.47434/JEREDA.2.1.2021.34.

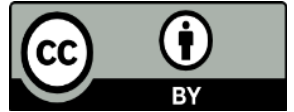

Copyright (c) 2021 The author(s) of this article retain(s) the copyright.

Volume 2, Number 1 


\section{PUBLIC INTEREST STATEMENT}

This appears to be the most recent study on enrolment in South-South Nigeria. It is a modern-day practice to use the understanding of events of yesterday and today to understand likely events of tomorrow. This study made forecast extending from 2020 to 2031 using the moving average times series approach based on past enrolment data from the three federal universities.

\section{INTRODUCTION}

Every year, the population of applicants seeking admission continue to rise. The crowd at the Joint Admissions and Matriculation Board (JAMB) assessment centres shows how the market for university education has risen exponentially in recent years. Records from undergraduate matriculation examination bodies showed that over one million secondary school leavers annually seek placement into Nigerian universities (JAMB Registration Statistics, 2019). The total of admission received in 2009 from $1,185,579$ candidates sitting for examination by the Joint Admission and Matriculation Board was 211,991, 17.9 per cent of all candidates being admitted (Ojerinde, 2011). This is evident that less than 20 per cent of those who sought for placement into universities were admitted. As low as this may be, Nigerians qualified to be given university education ought to be admitted without any form of discernment on the grounds of religion, gender, state of origin, outrageous charges, quota system policy among others.

The inadequate number of staff seems to have generated admission problem because the university is constrained to limit her admissions to tally with the academic staff strength. In 2006, the overall number of instructors in the Nigerian university system was 27,394, but for successful course implementation across the disciplines, about 50,000 is needed (Federal Ministry of Education, 2009). This indicates a short drop of 19,548 academic staff in the period. Acute shortage of infrastructural facilities like lecture halls, classrooms, hostels, laboratories, libraries and office accommodation affect students' intake seriously. Most Universities lack these facilities (Mbon, Omorobi, Owan \& Ekpenyong (2019) and because of this, only a few applicants are admitted. Universities can only admit numbers of candidates that hostels and lecture halls can accommodate (Ibrahim \& Ahmed, 2012). Government's effort in expanding university education is supposed to be supplemented with corresponding increased financing of the education sector. Unfortunately, finances allocated to the sector over the years in Nigeria have consistently fallen short of the $26 \%$ of annual budgetary apportionment to the education sector as suggested by UNESCO.

For example, it has been reported that only $7.25 \%, 4.83 \%, 6.16 \%, 8.20 \%$, $8.54 \%, 9.94 \%, 7.76 \%, 6.53 \%, 7.39 \%$ and $7.03 \%$ of Nigeria's total budget were apportioned to the Education sector in 2009, 2010, 2011, 2012, 2013, 2014, 2015, 2016, 2017 and 2018 respectively (Odigwe \& Owan, 2019) despite huge external borrowings which has put the nation in debts (Ekaette, Ekpenyong \& Owan 2019). The poor funding led to many programmes in the universities being denied accreditation. Thus, poor funding militates against the government's effort in ensuring a high enrolment rate. Apart from this, male dominance and female subordination are a long-standing assumption in the difference between boys and girls who take part in education in Africa (Uwakwe, Ajibola, Benedicta \& Omobola, 2008).

A study revealed that access to universities in Nigeria was low when related to the total number of eligible candidates and there existed variances in access for male and female candidates (Agboola \& Ofoegbu, 2010) in favour of males (Ahmed, 2010). In explaining, the outcomes from some studies have indicated that women, just like other educationally disadvantaged class (e.g., nomads, migrant fishermen and street children) maintain a very poor level of access to university education in Nigeria 
(Nwajiuba, 2011; Oyebade, 2008). An extensive report revealed that JAMB bewailed the decrease in the number of female candidates who sat for the UTME examination from 438,703 in 2003 to 353,834 in 2004 (Nwajiuba, 2011). The study of Esomonu and Adirika (2012) indicated that only $41.37 \%$ of female students who applied to JAMB were admitted. In providing reasons for the shortfall in female enrolment, a more recent study found that poverty, male child desire, cultural and religious values were the causes of female poor enrollment to technical education programmes in Rivers State, Nigeria (Dokubo \& Deebom, 2017). The research of Chibuogwu (2016) further showed that the two major difficulties confronting women are - merging their studies with family tasks and the lack of sufficient expertise in computer.

Merit criterion entails that candidates that have very high scores in matriculation examinations are first given priority for any course they choose before other applicants can be considered. It has been documented that the criteria for admission into higher education were $45 \%$ for merit, $35 \%$ for catchment area and $20 \%$ for educationally less developed states (Obasi \& Ohia, 2015). It has been contended by a study that the merit criteria have a beneficial impact on graduate quality; however, the two other criteria have a detrimental effect on graduates' quality as they foster mediocrity (Obasi \& Ohia, 2015). The finding of another research which indicated that the major hindrance to access was the fewer number of universities as compared to the number of eligible candidates who sought to admittance (Esomonu \& Adirika, 2012). In an extensive investigation, it was found that the quality of students' performance admitted on merit and those admitted through catchment area criterion differed significantly; while the academic performance of students admitted through catchment area, university discretion and educationally disadvantaged states criterion had no significant difference; the rate of wastage among students admitted on merit was lesser when compared to those admitted on the catchment area criterion (Adeyemi, 2001). This means that admission through the merit criterion creates efficiency in higher education institutions. Based on this indication, some researchers recommended that $80 \%$ of admission should be offered purely on merit and a standardized test should be used as post UTM Examination (Okeke \& Isiozo, 2013).

The Catchment area criterion was created based on the quest to provide equivalent openings to all candidates for admission into federal universities. Under this criterion, concern usually is granted to candidates whose region falls within the catchment area of the university. All the states in Nigeria are catchment areas to some universities while all the local government areas of each state serve as catchment area to state-owned universities. However, research has shown that the catchment area criterion and the quota system have had a high impact on the admission of students (Omeje, Egwa \& Adikwu, 2016). In a survey, Akpan (1990) outlined two characteristics that were counterproductive to national integration - first, universities choose their undergraduates mainly from their neighbouring states and regions; secondly, the movement of students from one region of the country to another was in one direction - mostly from South to North.

\section{STATEMENT OF THE PROBLEM}

By the military Decree No. 2 of 1978, which brought about the creation of an organization known as Joint Admission and Matriculation Board, the federal government made effort to make sure that quality higher education, as well as impartial representation of all states in the tertiary education, is laudable. Among the objectives of this agency was the creation of mechanisms for streamlining admissions into tertiary institutions on an identical and impartial basis. That is to say, the crux of establishing the Joint Admission and Matriculation Board was to advance uniform/identical criteria for admission into tertiary institutions and to ensure 
that selection of candidates for admission was based on merit. However, there seems to have existed a conflict between the identified objectives of Joint Admission and Matriculation Board and what is practiced. JAMB exams tend to be used by the government as a mere political weapon to equalise educational opportunities between educationally privileged states and deprived states. It has been suggested that the JAMB entry pattern requires 45 per cent for merit, 35 per cent for catchment areas and 20 per cent for less developed states in education (Ukertor, 2010). The 45\% merit admission criterion gives precedence to applicants who scored greater than the cut-off marks on matriculation examinations. These high score applicants are to be given priority for their course of choice.

The $35 \%$ catchment area admission criterion is expected to provide an equivalent chance to all candidates from states that fall within the area the university is located irrespective of their low scores. Furthermore, indigenous candidates from states that are deemed educationally deficient, are granted preferential treatment for admission by allocating lower cut-off marks on matriculation exams in the 20 per cent allocated for the criterion of admission to Educationally Less Developed States (ELDS). Regrettably, it appears like this system has been greatly exploited. The above condition contributed to the battle for the allocation of scarce admission spaces and hence resulted in activities such as assessment fraud, admission corruption and manipulation of marks obtained (Ukertor, 2010). It is believed that the structures that exist in Nigerian universities should provide for an increased enrolment for candidates seeking admission. This study covering from 2010-2019, was conducted based on this background to assess the enrolment trend in Federal universities, with forecast made up to the year 2031.

\section{PURPOSE OF THE STUDY}

The central aim of this study was to evaluate the enrolment patterns in federal universities in South-South
Nigeria based on three criteria and to make future forecast based on the current trends. Specifically, this study sought to:

1. examine the enrolment pattern in federal universities in terms of gender from 2010 - 2019;

2. evaluate the enrolment pattern in federal universities based on the merit criterion from 2010 - 2019;

3. study the enrolment pattern in federal universities based on the catchment area criterion from 2010 - 2019;

4. forecast the enrolment pattern in federal universities in terms of gender for the next twelve years using the current trends;

5. predict future enrolment in federal universities based on the merit criterion for the next twelve yearsusing past trends;

6. determine the prospective enrolment patterns in federal universities based on the catchment criterion in the next twelve years following past data.

\section{RESEARCH QUESTIONS}

1. What is the enrolment pattern in federal universities in terms of gender from 2010 - 2019?

2. What is the enrolment pattern in federal universities in terms of the merit criterion from $2010-2019$ ?

3. What is the enrolment pattern in federal universities in terms of catchment area criterion from 2010 2019?

4. What will be the enrolment pattern in federal universities in terms of gender, twelve years to come based on the current trends?

5. What will be the future enrolment in federal universities based on the merit criterion in twelve years using past trends?

6. What are the prospective enrolment patterns in federal universities based on the catchment criterion in the next twelve years following past data?

\section{METHODOLOGY \\ Research Designs}

The descriptive survey research under the quantitative methodology, was 
adopted for this research. This design allows researchers to study existing phenomena as they occur naturally in the population, without any form of manipulation.

\section{Population and Sample}

Four federal universities in SouthSouth Nigeria that offered admission from 2010/2011 academic session to $2019 / 2020$ academic session formed the population for the research (see Table 1). The researchers used the purposive sampling technique to choose universities for the research based on the generations of their establishment. In using this technique, one university was selected from each generation of universities in South-South Nigeria based. This resulted in the selection of three out of the four universities in the population.

Table 1: Federal universities that had offered admission from the $2010 / 2011$ academic session

\begin{tabular}{|c|c|c|c|}
\hline Name of universities & Location/State & $\begin{array}{l}\text { Generation } \\
\text { of } \\
\text { university }\end{array}$ & Selected \\
\hline University of Benin (UNIBEN) & Edo & First & Yes \\
\hline University of Calabar (UNICAL) & Cross River & Second & Yes \\
\hline $\begin{array}{l}\text { University of Port Harcourt } \\
\text { (UNIPORT) }\end{array}$ & Rivers & Second & No \\
\hline University of Uyo (UNIUYO) & Akwa Ibom & Third & Yes \\
\hline
\end{tabular}

\section{Instrument for Data Collection}

Secondary data were gathered with an instrument titled "Enrolment in Federal Universities Checklist (EFUC)." This instrument has columns for gender, merit and catchment area criteria enrolment figures. The checklist used for the gathering of data was pre-validated for content validity by two Educational Planning experts and two specialists in measurement and evaluation of the Faculty of Education, University of Calabar. They assessed the adequacy and clarity of the items listed in the checklist. Their corrections, modifications and suggestions were followed in preparing the final draft of the instrument.

\section{Method(s) of Data Analysis}

A written request was sent to the Directors of Academic Planning Division of each of the universities to be able to access the data needed. Enrolment data covering the period of 2010 to 2019 were obtained. Two trained research aides were involved to help the researchers in organizing the data gathered using the "Enrolment in Federal Universities Checklist (EFUC)". The data collected was prepared and encoded into a spreadsheet software (MS-Excel 2019) and described with the aid of summation and percentages, while line graphs and bar charts (where applicable) were used to illustrate the enrolment patterns. Forecasting up to the year 2031 was then performed using the data collected from 2010 to 2019, to present a future enrolment outlook in Federal universities in South-South Nigeria, in terms of the three criteria.

\section{RESULTS}

Research Question 1: What is the enrolment pattern in federal universities in terms of gender from 2010 - 2019? 
Journal of Educational Research in Developing Areas (JEREDA)

Vol. 2. Issue 1, Pp. 34-51, 2021

http://www.jeredajournal.com

E-mail: info@jeredajournal.com

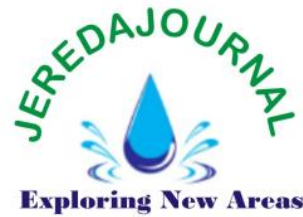

Table 2: Enrolment in federal universities in South-South, Nigeria from 2010 2019 in terms of gender

\begin{tabular}{llcccc}
\hline Year & Gender & $\begin{array}{c}\text { University of } \\
\text { Benin }\end{array}$ & $\begin{array}{c}\text { University of } \\
\text { Calabar }\end{array}$ & University of Uyo & Total \\
\hline $2010 / 11$ & Male & $3393(61)$ & $1948(54)$ & $1235(48)$ & 6576 \\
& Female & $2166(39)$ & $1668(46)$ & $1339(52)$ & 5173 \\
$2011 / 12$ & Male & $3576(61)$ & $1824(59)$ & $1969(62)$ & 7369 \\
& Female & $2325(39)$ & $1269(41)$ & $1223(38)$ & 4817 \\
$2012 / 13$ & Male & $3497(60)$ & $2871(60)$ & $2097(57)$ & 8445 \\
& Female & $2314(40)$ & $1891(40)$ & $1583(43)$ & 5788 \\
$2013 / 14$ & Male & $3946(56)$ & $3079(58)$ & $1256(36)$ & 8281 \\
& Female & $3096(44)$ & $2212(42)$ & $2191(64)$ & 7499 \\
$2014 / 15$ & Male & $3564(56)$ & $3661(67)$ & $2306(54)$ & 9531 \\
& Female & $2833(44)$ & $1792(33)$ & $1965(46)$ & 6590 \\
$2015 / 16$ & Male & $4171(53)$ & $2878(42)$ & $2166(54)$ & 9215 \\
& Female & $3668(47)$ & $3973(58)$ & $1838(46)$ & 9479 \\
$2016 / 17$ & Male & $3946(51)$ & $3998(52)$ & $2385(51)$ & 10329 \\
& Female & $3543(49)$ & $3764(48)$ & $2271(49)$ & 9578 \\
$2017 / 18$ & Male & $4330(51)$ & $3656(47)$ & $2581(52)$ & 10567 \\
& Female & $4139(49)$ & $4198(53)$ & $2426(48)$ & 10763 \\
$2018 / 19$ & Male & $4158(50.1)$ & $4650(50.1)$ & $2776(52)$ & 11584 \\
& Female & $4094(49.9)$ & $4632(49.9)$ & $2581(48)$ & 11307 \\
$2019 / 20$ & Male & $4543(49)$ & $4308(46)$ & $2972(52)$ & 11823 \\
& Female & $4690(51)$ & $5065(54)$ & $2736(48)$ & 12491 \\
\hline
\end{tabular}

Source: Academic Planning Unit of the universities under study, 2020.

Note: Percentage of enrolment are in parenthesis.

As shown in Table 2, the enrolment pattern for both male and female from 2010 to 2019 was dwindling. Male enrolment increased steadily from 2010 to 2012 before witnessing downswings and upswings from 2013 to 2019 (making it unstable). A stable female enrolment was only recorded between 2011 and 2013. As shown in Fig 3, males had a higher enrolment rate across federal universities than female. Specifically, higher male enrolment rates were recorded steadily between 2010 to 2014, as well as in 2016 and 2018.

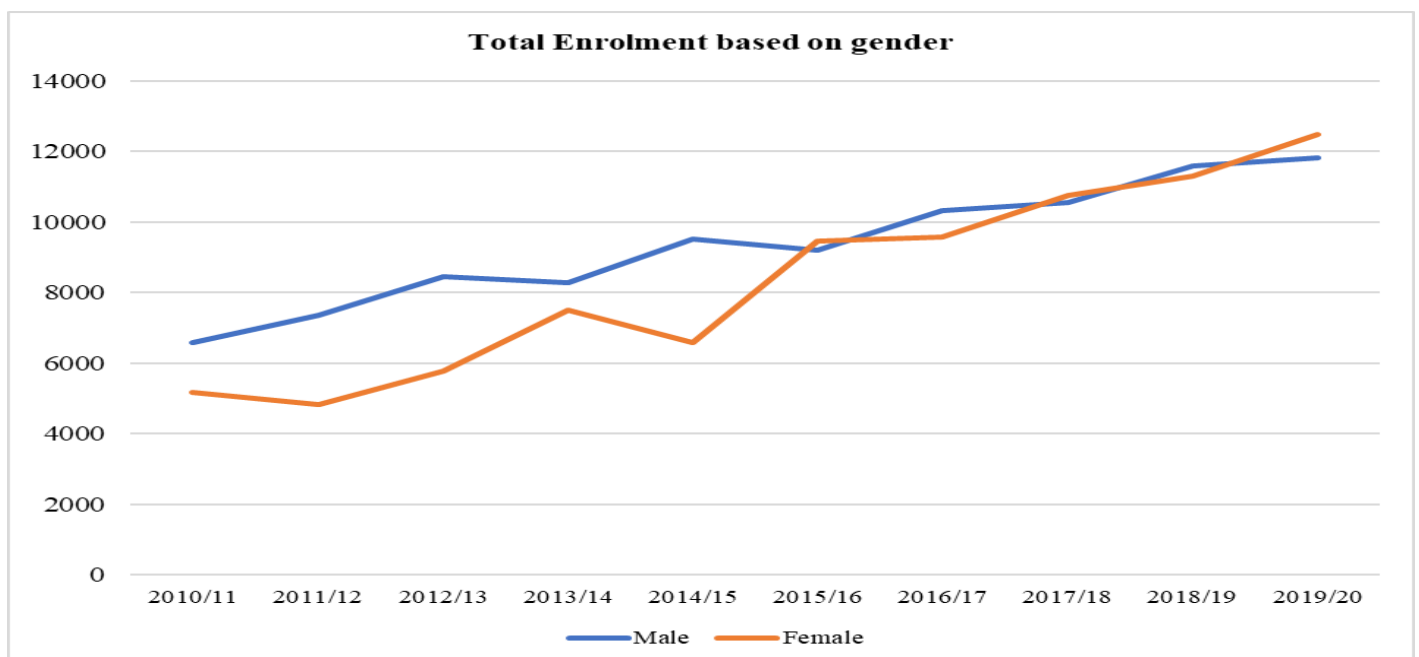

Figure 1: Total gender enrolment for the three federal universities from 2010 2019 
Journal of Educational Research in Developing Areas (JEREDA)

Vol. 2. Issue 1, Pp. 34-51, 2021

http://www.jeredajournal.com

E-mail: info@jeredajournal.com

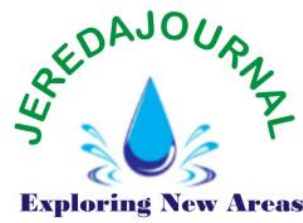

Research Question 2: What is the in terms of the merit criterion from 2010 enrolment pattern in federal universities -2019 ?

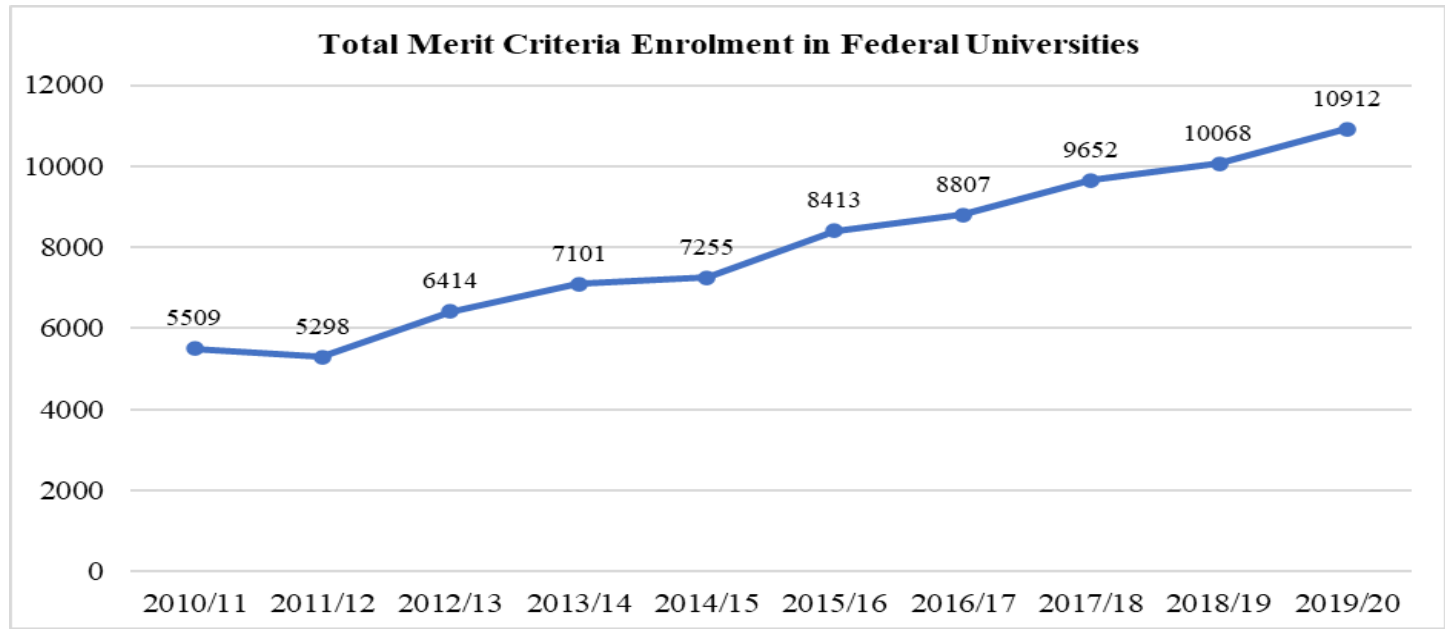

Figure 2: Total merit enrolment for federal universities from 2010 - 2019

The results in Figure 2 showed that total enrolment in federal universities in terms of merit criterion in 2010/2011 session was 5509. This enrolment decreased in 2011/2012 session to 4298. From 2012/2013 session, enrolment increased steadily from 6414 to $7101,7255,8413,8807$,
9652, 10068 and 10912 in 2013/2014, 2014/2015, 2015/2016, 2016/2017, 2017/2018, 2018/2019 and 2019/2020 sessions respectively. Generally, enrolment pattern across the universities under consideration over the years had an upward pattern. The situation across the three universities is presented in Figure 3.

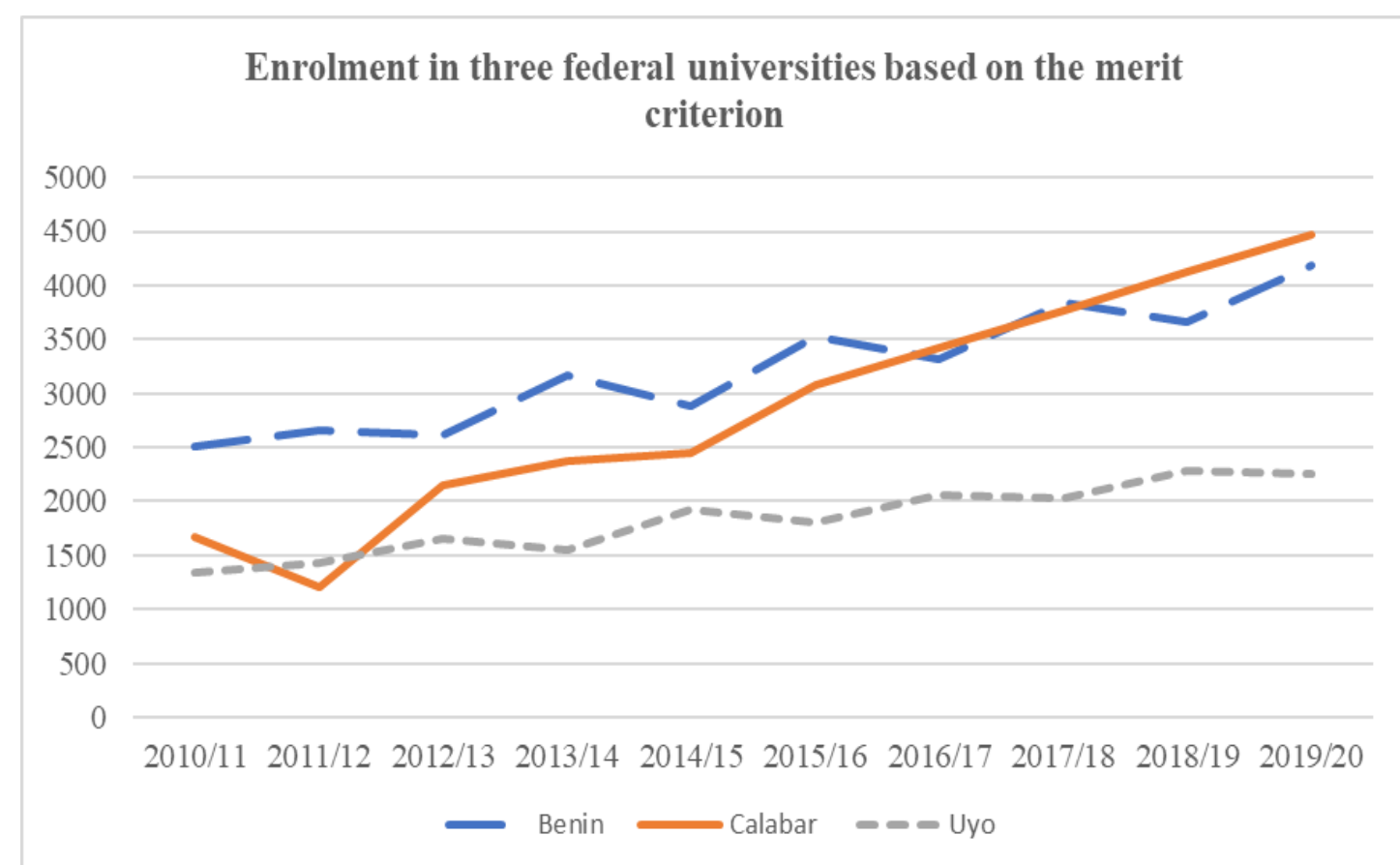

Figure 3: Enrolment pattern in each of the federal universities in terms of merit criterion from 2010 - 2019 
As illustrated in Figure 3., the merit criterion enrolment pattern in the three universities (partially) has been quite unsteady except for the university of Calabar which maintained an upward pattern from 2014 to 2019. In the university of Uyo, a steady upward enrolment pattern based on the merit criterion was recorded between 2010 and
2012. Apart from these few stabilities, there have been fluctuations in the waveform across the three universities under focus.

Research Question 3: What is the enrolment pattern in federal universities in terms of the catchment area criterion from $2010 \quad$ 2019?

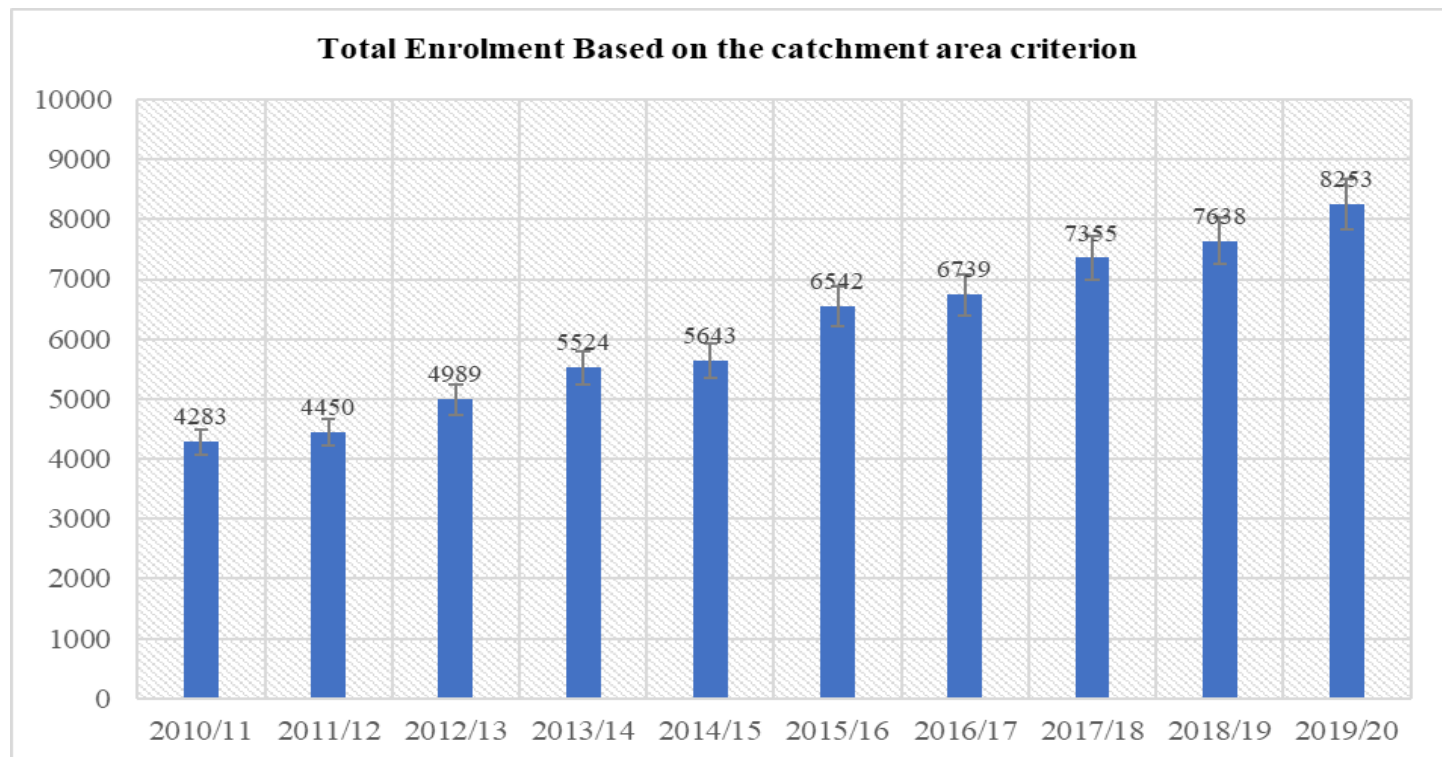

Figure 4: Total enrolment in federal universities from 2010 - 2019 based on the catchment area criterion

The result in Figure 4 showed that total enrolment in federal universities in terms of catchment area criterion in $2010 / 2011$ session was 4283. This enrolment increased in 2011/2012 session to 4450 . In the same vein, from $2012 / 2013$ session, enrolment increased steadily from 4989 to $5524,5643,6542$, $6739,7355,7638$, and 8253 in 2013/2014, 2014/2015, 2015/2016, 2016/2017, 2017/2018, 2018/2019 and in 2019/2020 sessions respectively. Furthermore, the result indicates that the universities under consideration, tend to adhere strictly to the admission policy of allocating $35 \%$ to the catchment area criterion. However, it was shown that in the 2011/2012 academic session, only the University of Calabar had $41 \%$ enrolment for the catchment area criterion, which was far above the stated criterion. Generally, enrolment pattern across the universities under consideration over the years had an upward trend. The situation at the institutional level is presented in Figure 5. 
Journal of Educational Research in Developing Areas (JEREDA)

Vol. 2. Issue 1, Pp. 34-51, 2021

http://www.jeredajournal.com

E-mail: info@jeredajournal.com
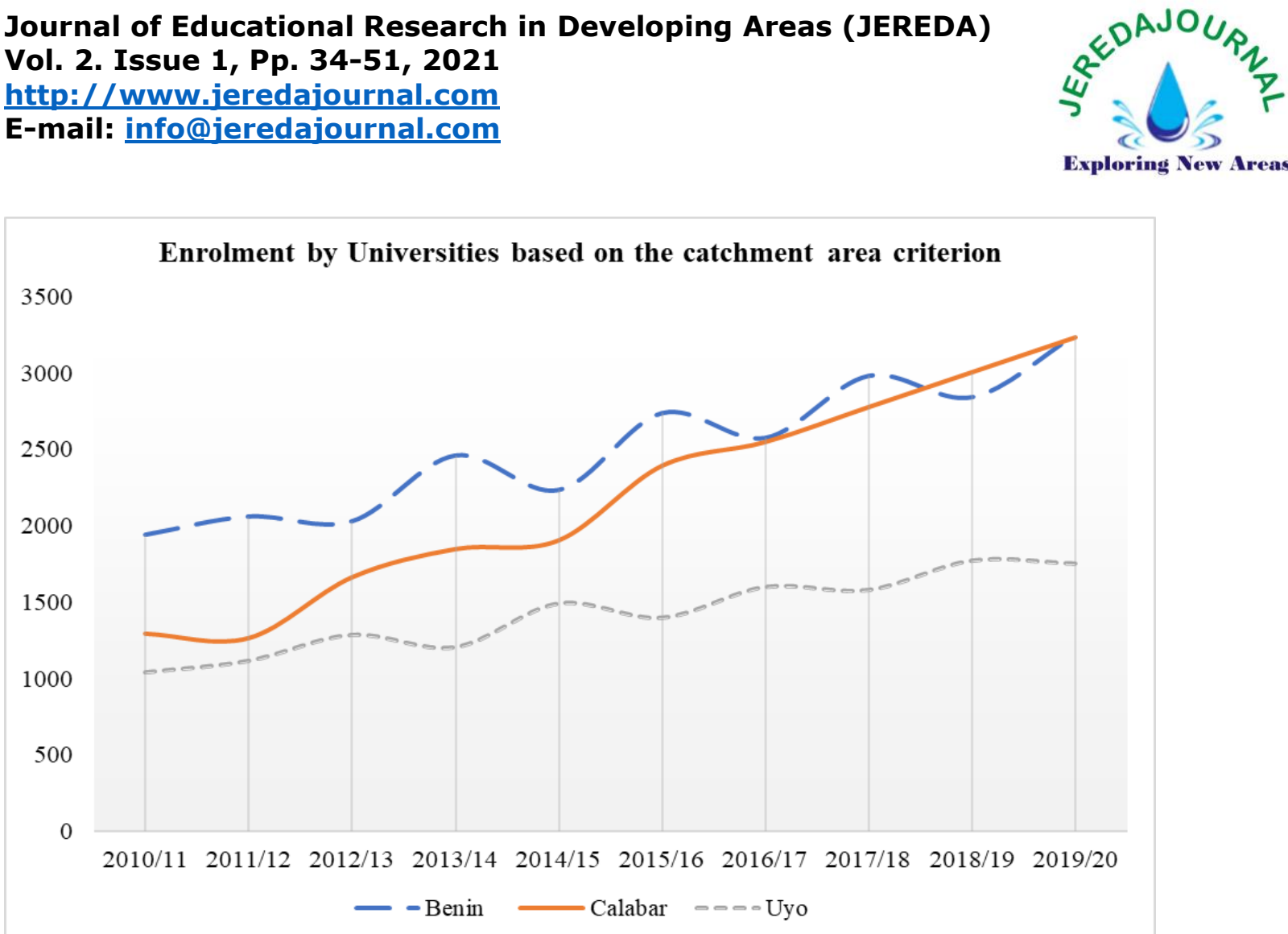

Figure 5: Enrolment pattern in each of the federal universities in terms of the catchment area criterion from 2010 - 2019

A critical look at Figure 5 shows that at the institutional level, there was a dwindling enrolment (based on the catchment area criterion) across the three universities under study from 2010 to 2019. The enrolment instability is more notable in the University of Benin and Uyo. The University of Calabar recorded a consistent upward trend in enrolment based on the catchment area criterion, from 2015 to 2019. Relatively, the University of Benin maintained a higher number of students' enrolment than the university of Calabar and Uyo in that order respectively, based on the catchment area criterion between 2010 and 2017, with the University of Calabar topping the enrolment chart in 2018 and 2019.

Research Question 4: What will be the enrolment pattern in federal universities in terms of gender, twelve years to come based on the current trends? 
Journal of Educational Research in Developing Areas (JEREDA)

Vol. 2. Issue 1, Pp. 34-51, 2021

http://www.jeredajournal.com

E-mail: info@jeredajournal.com

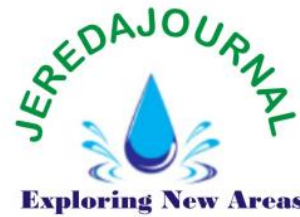

Table 3: Forecasted students enrolments based on gender in Federal universities (2020 - 2031)

\begin{tabular}{|c|c|c|c|c|c|}
\hline Year & ender & $\begin{array}{c}\text { University of } \\
\text { Benin }\end{array}$ & $\begin{array}{c}\text { University of } \\
\text { Calabar }\end{array}$ & $\begin{array}{c}\text { University of } \\
\text { Uyo }\end{array}$ & Total \\
\hline \multirow[t]{2}{*}{$2020 / 21$} & Male & $\begin{array}{c}4371(4161- \\
4544)\end{array}$ & $\begin{array}{c}5302(4653- \\
5701)\end{array}$ & $\begin{array}{c}3168(2385- \\
3668)\end{array}$ & $\begin{array}{c}12841(12299 \\
13382)\end{array}$ \\
\hline & male & $\begin{array}{c}4644(4300- \\
4960)\end{array}$ & $\begin{array}{c}5499(4154- \\
6430)\end{array}$ & $\begin{array}{c}2891(2588- \\
3285)\end{array}$ & $\begin{array}{c}13034(11779- \\
14735)\end{array}$ \\
\hline \multirow[t]{2}{*}{$2021 / 22$} & Male & $\begin{array}{c}4755(4573- \\
4968)\end{array}$ & $\begin{array}{c}4960(4270- \\
5581)\end{array}$ & $\begin{array}{c}3364(2544- \\
3837)\end{array}$ & $\begin{array}{c}13079(12273- \\
13627)\end{array}$ \\
\hline & Female & $\begin{array}{c}5240(4861- \\
5599)\end{array}$ & $\begin{array}{c}5933(4745- \\
7291)\end{array}$ & $\begin{array}{c}3047(2747- \\
3444)\end{array}$ & $\begin{array}{c}14220(12611- \\
15658)\end{array}$ \\
\hline \multirow[t]{2}{*}{$2022 / 23$} & Male & $\begin{array}{c}4583(4362- \\
4769)\end{array}$ & $\begin{array}{c}5954(5014- \\
6545)\end{array}$ & $\begin{array}{c}3560(2704- \\
4007)\end{array}$ & $\begin{array}{c}14097(13209- \\
14790)\end{array}$ \\
\hline & Female & $\begin{array}{c}5195(4766- \\
5577)\end{array}$ & $\begin{array}{c}6367(4754- \\
7546)\end{array}$ & $\begin{array}{c}3202(2907- \\
3604)\end{array}$ & $\begin{array}{c}14764(13444- \\
16581)\end{array}$ \\
\hline \multirow[t]{2}{*}{$2023 / 24$} & Male & $\begin{array}{c}4967(4774- \\
5193)\end{array}$ & $\begin{array}{c}5612(4667- \\
6390)\end{array}$ & $\begin{array}{c}3755(2863- \\
4177)\end{array}$ & $\begin{array}{c}14334(13219- \\
14999)\end{array}$ \\
\hline & Fema & $\begin{array}{c}5791(5333- \\
6209)\end{array}$ & $\begin{array}{c}6801(5367- \\
8385)\end{array}$ & $\begin{array}{c}3357(3066- \\
3764)\end{array}$ & $\begin{array}{c}15949(14277- \\
17503)\end{array}$ \\
\hline \multirow[t]{2}{*}{$2024 / 25$} & Male & $\begin{array}{c}4795(4563- \\
4993)\end{array}$ & $\begin{array}{c}6605(5434- \\
7331)\end{array}$ & $\begin{array}{c}3951(3022- \\
4347)\end{array}$ & $\begin{array}{c}15351(14179- \\
16138)\end{array}$ \\
\hline & Female & $\begin{array}{c}5746(5244- \\
6182)\end{array}$ & $\begin{array}{c}7235(5392- \\
8623)\end{array}$ & $\begin{array}{c}3512(3226- \\
3923)\end{array}$ & $\begin{array}{c}16493(15112- \\
18424)\end{array}$ \\
\hline \multirow[t]{2}{*}{$2025 / 26$} & Male & $\begin{array}{c}5180(4976- \\
5417)\end{array}$ & $\begin{array}{c}6264(5103- \\
7159)\end{array}$ & $\begin{array}{c}4147(3181- \\
4517)\end{array}$ & $\begin{array}{c}15591(14206- \\
16330)\end{array}$ \\
\hline & Fema & $\begin{array}{c}6342(5815- \\
6810)\end{array}$ & $\begin{array}{c}7669(6019- \\
9449)\end{array}$ & $\begin{array}{c}3668(3386- \\
4083)\end{array}$ & $\begin{array}{c}17679(15948- \\
19344)\end{array}$ \\
\hline \multirow[t]{2}{*}{$2026 / 27$} & Male & $\begin{array}{c}5008(4765- \\
5217)\end{array}$ & $\begin{array}{c}7257(5883- \\
8087)\end{array}$ & $\begin{array}{c}4343(3340- \\
4686)\end{array}$ & $\begin{array}{c}16608(15179- \\
17456)\end{array}$ \\
\hline & $\mathrm{F}$ & $\begin{array}{c}6297(5730- \\
6780)\end{array}$ & $\begin{array}{c}8103(6056- \\
9675)\end{array}$ & $\begin{array}{c}3823(3545- \\
4243)\end{array}$ & $\begin{array}{c}18223(16784- \\
20263)\end{array}$ \\
\hline \multirow[t]{2}{*}{$2027 / 28$} & Male & $\begin{array}{r}5392( \\
56\end{array}$ & $\begin{array}{r}6916 \\
79\end{array}$ & $\begin{array}{c}4539(3500- \\
4856)\end{array}$ & $\begin{array}{c}16847(15217- \\
17637)\end{array}$ \\
\hline & Fema & $\begin{array}{c}6893(6303- \\
7406)\end{array}$ & $\begin{array}{c}8537(6693- \\
10492)\end{array}$ & $\begin{array}{c}3978(3705- \\
4402)\end{array}$ & $\begin{array}{c}19408(17620- \\
21182)\end{array}$ \\
\hline \multirow[t]{2}{*}{$2028 / 29$} & Male & $\begin{array}{c}5220(4967- \\
5440)\end{array}$ & $\begin{array}{c}7909(6351- \\
8825)\end{array}$ & $\begin{array}{c}4734(3659- \\
5026)\end{array}$ & $\begin{array}{c}17863(16199- \\
18754)\end{array}$ \\
\hline & $\mathrm{F}$ & $\begin{array}{c}6848(6220- \\
7372)\end{array}$ & $\begin{array}{c}8971(6737- \\
10710)\end{array}$ & $\begin{array}{c}4133(3864- \\
4562)\end{array}$ & $\begin{array}{c}19952(18458- \\
22100)\end{array}$ \\
\hline \multirow[t]{2}{*}{$2029 / 30$} & Male & $\begin{array}{c}5604(5380- \\
5864)\end{array}$ & $\begin{array}{c}7568(6037- \\
8636)\end{array}$ & $\begin{array}{c}4930(3818- \\
5196)\end{array}$ & $\begin{array}{c}86212(16244- \\
18929)\end{array}$ \\
\hline & Fema & $\begin{array}{c}7444(6796- \\
7996)\end{array}$ & $\begin{array}{c}9405(7381- \\
11519)\end{array}$ & $\begin{array}{c}4288(4024- \\
4721)\end{array}$ & $\begin{array}{c}21137(19296- \\
23018)\end{array}$ \\
\hline \multirow[t]{2}{*}{$2030 / 31$} & Male & $\begin{array}{c}5432(5170- \\
5664)\end{array}$ & $\begin{array}{c}8561(6831- \\
9550)\end{array}$ & $\begin{array}{c}5126(3977- \\
5366)\end{array}$ & $\begin{array}{c}19119(17231- \\
20040)\end{array}$ \\
\hline & Fema & $\begin{array}{c}7399(6714- \\
7961)\end{array}$ & $\begin{array}{c}9839(7432- \\
11731)\end{array}$ & $\begin{array}{c}4444(4184- \\
4881)\end{array}$ & $\begin{array}{c}21682(20134- \\
23935)\end{array}$ \\
\hline \multirow[t]{2}{*}{$2031 / 32$} & Male & $\begin{array}{c}5816(5583- \\
6087)\end{array}$ & $\begin{array}{c}8220(6522- \\
9356)\end{array}$ & $\begin{array}{c}5322(4136- \\
5536)\end{array}$ & $\begin{array}{c}19358(17281- \\
20209)\end{array}$ \\
\hline & Female & $\begin{array}{c}7995(7291- \\
8584)\end{array}$ & $\begin{array}{c}10273(8081- \\
12535)\end{array}$ & $\begin{array}{c}4599(4343- \\
5041)\end{array}$ & $\begin{array}{c}22867(20973- \\
24851)\end{array}$ \\
\hline
\end{tabular}

Source: Authors' Estimation and forecast

Note: Range values in parenthesis are the lower and upper confidence bounds of the forecast at $95 \% \mathrm{CI}$

The result in Table 3 reveals that in the future (in twelve years' time), the
University of Uyo will witness an upward pattern in the enrolment of male students from 2020 to 2031. In the 
university of Calabar and Benin, the pattern is unstable, reflecting potential fluctuations in the enrolment of male students. However, in a relative sense, the University of Calabar is likely to admit more male students than the University of Benin and Uyo in that order respectively. The enrolment of female students in the university of Calabar and Uyo respectively, will likely increase steadily without any form of decline. However, the depiction in the graph for the university of Benin is glaringly different due to the inconsistencies in the enrolment pattern of female students.
Comparatively, the university of Calabar, followed by the University of Benin will admit more female students than the university of Uyo between 2020 and 2031. The comparison between male and female students' enrolment from 2020 to 2031 across all the federal universities studied is presented in Fig. 6. The result of the analysis presented in Fig. 6 revealed that the future female enrolment of students in universities from 2020 to 2031 will be greater than that of male.

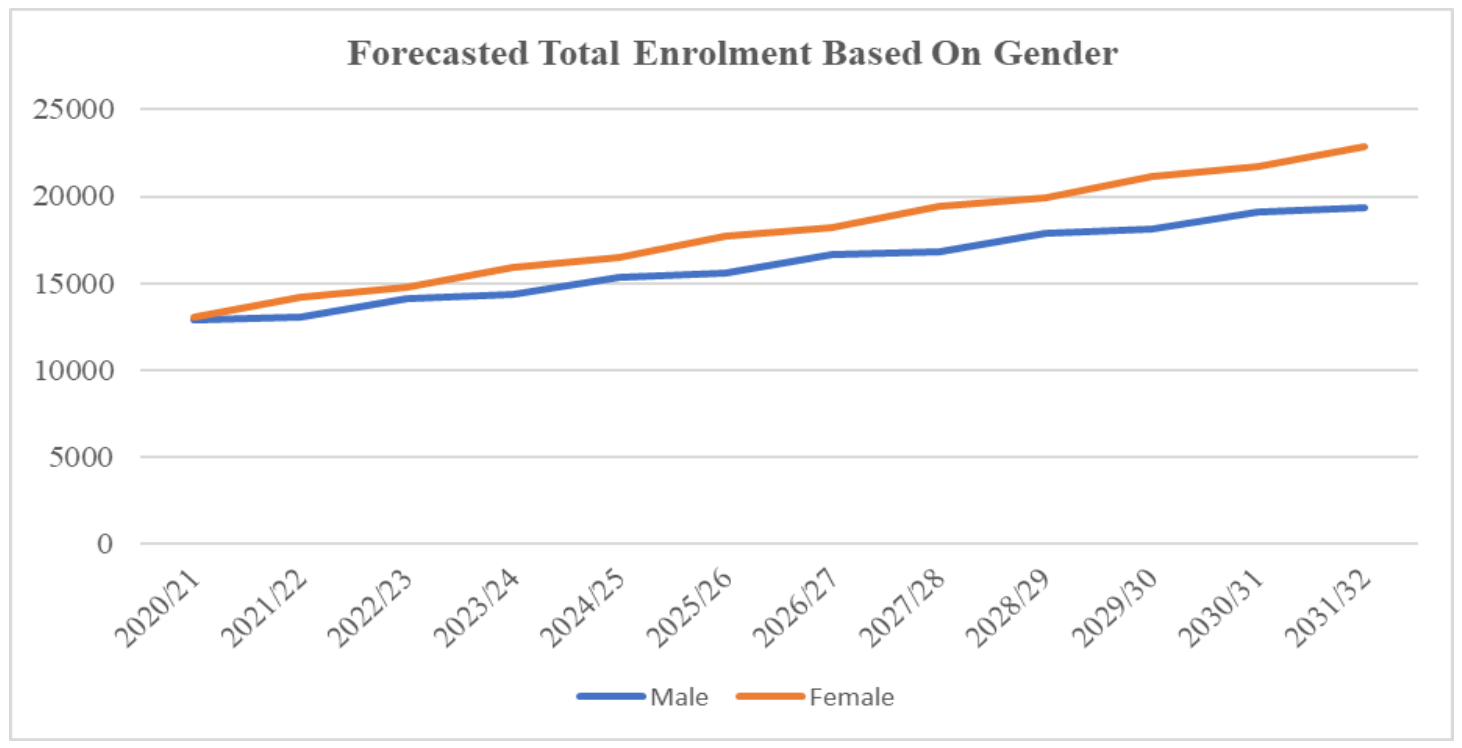

Figure 6: Male versus female forecasted enrolment in federal universities

Research Question 5: What will be the future enrolment panorama in federal universities based on the merit criterion in twelve years' time using past patterns? 
Journal of Educational Research in Developing Areas (JEREDA)

Vol. 2. Issue 1, Pp. 34-51, 2021

http://www.jeredajournal.com

E-mail: info@jeredajournal.com

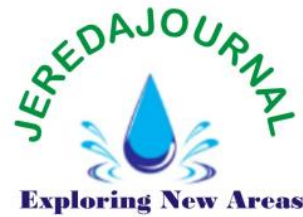

Table 4: Forecasted enrolment pattern in federal universities from 2021 to 2031 based on the merit criterion

\begin{tabular}{lcccc}
\hline Year & University of Benin & University of Calabar & University of Uyo & Total \\
\hline $2020 / 21$ & $4037(3803-4270)$ & $4810(4257-5363)$ & $2522(2412-2632)$ & $11369(10837-12125)$ \\
$2021 / 22$ & $4503(4241-4765)$ & $5157(4539-5776)$ & $2478(2355-2601)$ & $12138(11416-12744)$ \\
$2022 / 23$ & $4375(4088-4662)$ & $5505(4827-6183)$ & $2745(2610-2880)$ & $12625(12063-13431)$ \\
$2023 / 24$ & $4841(4531-5151)$ & $5853(5120-6585)$ & $2701(2555-2847)$ & $13395(12643-14049)$ \\
$2024 / 25$ & $4713(4381-5045)$ & $6200(5416-6984)$ & $2968(2812-3124)$ & $13881(13291-14735)$ \\
$2025 / 26$ & $5179(4827-5532)$ & $6548(5715-7380)$ & $2924(2758-3090)$ & $14651(13871-15352)$ \\
$2026 / 27$ & $5051(4679-5423)$ & $6895(6017-7774)$ & $3191(3015-3366)$ & $15137(14519-16037)$ \\
$2027 / 28$ & $5517(5127-5908)$ & $7243(6321-8165)$ & $3146(2963-3330)$ & $15906(15100-16654)$ \\
$2028 / 29$ & $5389(4981-5798)$ & $7591(6627-8554)$ & $3413(3221-3605)$ & $16393(15749-17339)$ \\
$2029 / 30$ & $5856(5430-6281)$ & $7938(6934-8942)$ & $3369(3169-3569)$ & $17163(16331-17955)$ \\
$2030 / 31$ & $5727(5286-6169)$ & $8286(7243-9329)$ & $3636(3428-3844)$ & $17649(16980-18639)$ \\
$2031 / 32$ & $6194(5736-6652)$ & $8634(7553-9714)$ & $3592(3376-3807)$ & $18420(17562-19255)$ \\
\hline
\end{tabular}

Source: Authors' Estimation and forecast

Note: Range values in parenthesis are the lower and upper confidence bounds of the forecast at $95 \%$ CI

The results shows that the future enrolment in federal universities, especially in the next twelve years, shall maintain a constant increase in a linear form between 2020 and 2031. This implies that federal universities in SouthSouth Nigeria shall continuously record a stable enrolment increase, based on the merit criterion, in the next twelve years going by the current enrolment patterns. A comparative analysis of the enrolment patterns of the three universities studied is presented in Figure 7. The future enrolment patterns of the three federal universities (based on the merit criterion), presented in Fig 7, shows that in the next twelve years, the University of Calabar will likely witness a consistent upward linear pattern. In the other two universities (Uyo and Benin), the enrolment pattern in the next twelve years is likely to fluctuate in a wave-like pattern. The fluctuations are likely going to be deeper in the University of Benin than the University of Uyo. Generally, based on the merit criterion, the University of Calabar is likely going to enrol more students than the University of Benin as well as the University of Uyo in that order.

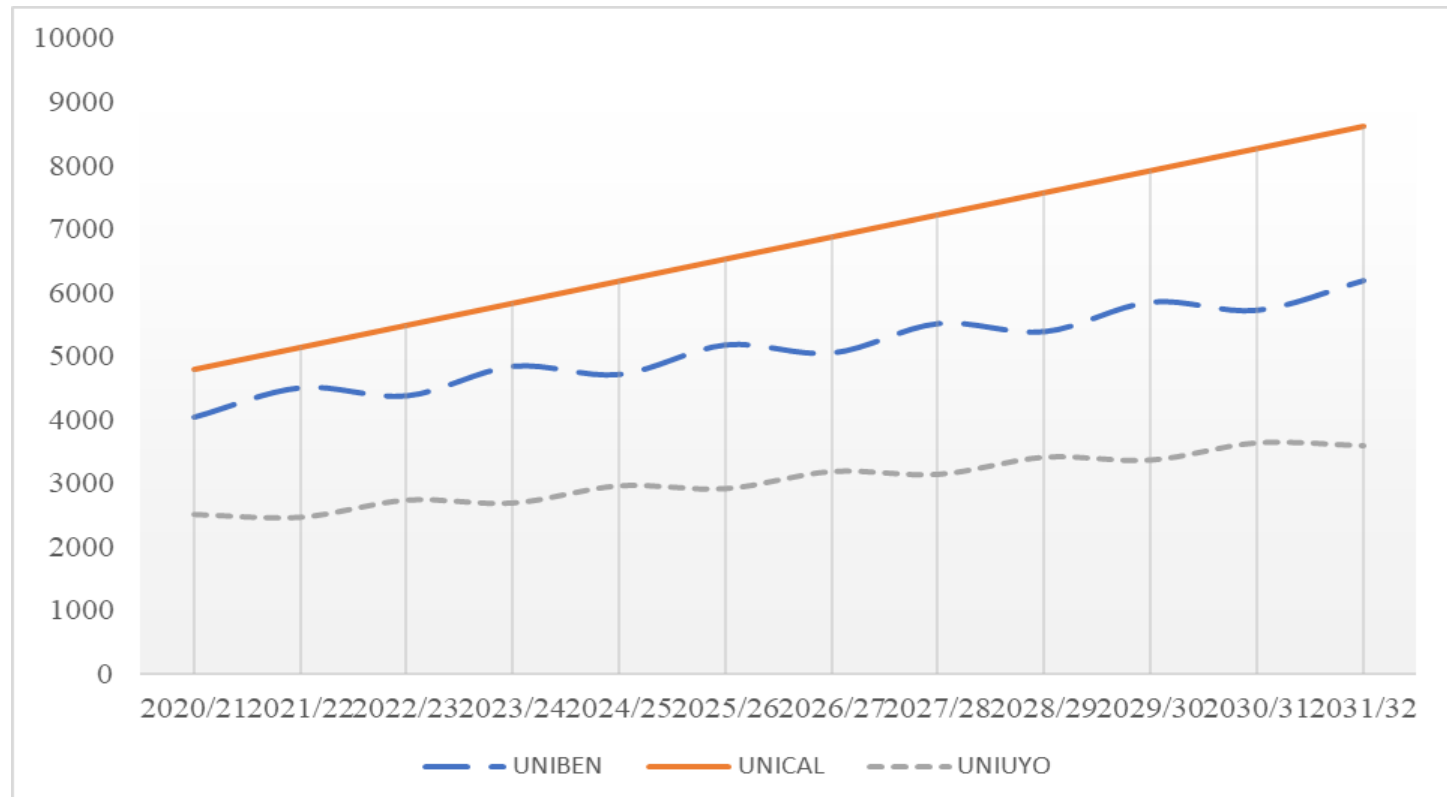


Journal of Educational Research in Developing Areas (JEREDA)

Vol. 2. Issue 1, Pp. 34-51, 2021

http://www.jeredajournal.com

E-mail: info@jeredajournal.com

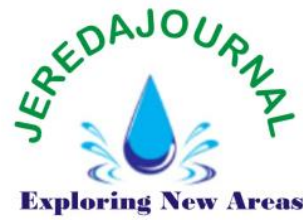

Figure 7. Forecasted future enrolment of three federal universities based on merit criterion

Research Question 6: What is the criterion in the next twelve years following past data? prospective enrolment pattern in federal universities based on the catchment area

Table 5: Forecasted prospective enrolment pattern in federal universities from 2021 to 2031 based on the catchment area criterion

\begin{tabular}{lcccc}
\hline Year & University of Benin & $\begin{array}{c}\text { University of } \\
\text { Calabar }\end{array}$ & University of Uyo & Total \\
\hline $2020 / 21$ & $3139(2957-3321)$ & $3470(3248-3692)$ & $1961(1875-2047)$ & $8570(8307-8970)$ \\
$2021 / 22$ & $3501(3298-3705)$ & $3699(3470-3928)$ & $1927(1831-2023)$ & $9127(8747-9430)$ \\
$2022 / 23$ & $3402(3179-3625)$ & $3928(3693-4164)$ & $2134(2029-2239)$ & $9464(9187-9891)$ \\
$2023 / 24$ & $3765(3524-4005)$ & $4155(3915-4400)$ & $2100(1986-2214)$ & $10020(9628-10351)$ \\
$2024 / 25$ & $3665(3407-3923)$ & $4386(4138-4635)$ & $2307(2185-2429)$ & $10358(10069-10811)$ \\
$2025 / 26$ & $4028(3754-4301)$ & $4615(4360-4871)$ & $2273(2143-2402)$ & $10916(10510-11271)$ \\
$2026 / 27$ & $3928(3639-4217)$ & $4844(4583-5106)$ & $2480(2344-2617)$ & $11252(10951-11731)$ \\
$2027 / 28$ & $4291(3987-4594)$ & $5074(4806-5341)$ & $2446(2303-2589)$ & $11811(11392-12191)$ \\
$2028 / 29$ & $4191(3874-4508)$ & $5303(5029-5576)$ & $2653(2503-2803)$ & $12147(11833-12650)$ \\
$2029 / 30$ & $4554(4223-4884)$ & $5532(5252-5811)$ & $2619(2463-2775)$ & $12705(12275-13109)$ \\
$2030 / 31$ & $4454(4111-4797)$ & $5761(5475-6046)$ & $2826(2664-2989)$ & $13041(12716-13569)$ \\
$2031 / 32$ & $4817(4461-5172)$ & $5990(5698-6281)$ & $2792(2624-2960)$ & $13599(13158-14028)$ \\
\hline
\end{tabular}

Source: Authors' Estimation and forecast

Note: Range values in parenthesis are the lower and upper confidence bounds of the forecast at $95 \% \mathrm{CI}$

As depicted in Table 5, the total future enrolment in federal universities from 2020 to 2031 shows an upward stable pattern. This implies that future enrolment in federal universities, based on the catchment area criterion, will keep increasing consistently for the next year twelve years. Consequently, there will likely be no decrease when the enrolment data across the universities are aggregated or taken together. However, a look at the result in Figure 8 shows the partial enrolment patterns in the respective universities studied. It has been revealed, based on the catchment area criterion, that the University of Calabar will maintain linear and upwardmoving enrolment pattern in the next twelve years. In the university of Benin and Uyo respectively, there will be fluctuations in the enrolment figures based on the catchment area criterion. Comparatively, the University of Calabar will record higher enrolment rates, based on the catchment area criterion than the other two universities. The University of Calabar is likely to be trailed by the University of Benin and Uyo in that order. 
Journal of Educational Research in Developing Areas (JEREDA)

Vol. 2. Issue 1, Pp. 34-51, 2021

http://www.jeredajournal.com

E-mail: info@jeredajournal.com

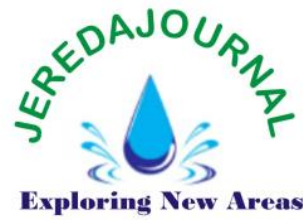

Forecasted Enrolment trend across three federal universities based on catchment area criterion

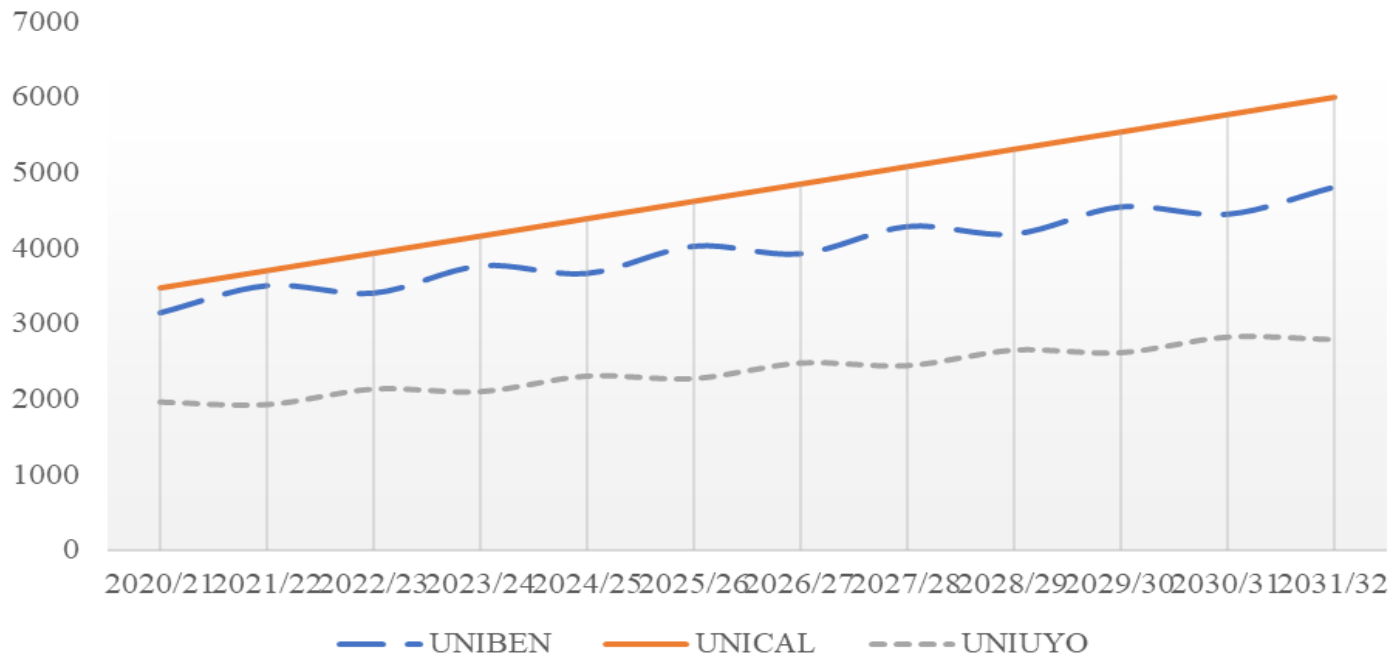

Figure 8. Partial prospective enrolment pattern across three federal universities in South-South Nigeria, based on the catchment area criterion

\section{DISCUSSION}

The first finding of this study indicated for gender, a difference in enrolment, with males having high enrolment than their female counterpart. Beyond the extent of gender gaps, as witnessed in the enrolment in universities, many education stakeholders argued that continuous investments in educating girls are necessary because girls are faced with abundant hindrances in their quest to receive quality education (Adeyemi \& Akpotu, 2004; Agu, 2004), The findings of this research agree with that of Obasi and Ohia (2015) which identified a host of restrictions with some customs in Nigeria that ascribes greater worth to a man than a woman. This finding implies that the process of enrolment encourages more male to be enrolled than their female counterparts in the university system as revealed in the study. Consequently, it dissuades the participation of women in university education and invalidates the principle of equal opportunities for education as laid down in Section 18(1) of the 1999 Constitution (as amended).

The second finding revealed that the enrolment pattern in federal universities in south-south, Nigeria from 2010 - 2019 in terms of merit criterion was consistently rising. The possible reasons for this increase may be attributed to societal perception of university education as a superb channel to a healthier life and economic growth. University education is perceived as of utmost importance in improving the lives of individuals and allow societies to develop and blossom. Furthermore, attempts to increase enrolment and boost the standards of education are severely hampered by long-term lack of university support and attrition of staff in the face of rising candidates pursuing university entry (Ekaette, Ekpenyong, et al., 2019). Another reason for the marginal increase in enrolment may be the result of underfunding, as many universities cannot enrol candidates more than their capacity. The result of this finding supports the views of Okoroma (2008) who stated that the observed fall in the standards of university education in Nigeria is speculated on the various admission policies. Similarly, Okeke and Isiozo (2013) thought that $80 \%$ of admission should be purely on merit. In as much as there seems to be an upward pattern in enrolment through merit criterion, the figures presented above are still not encouraging. The implication of this guideline in the coming years, more unmerited graduates than merited ones 
will be produced in universities, whereas those that ought to be trained would be deprived of the chances to accomplish their visions.

The third finding of this study showed that the pattern of enrolment in federal universities in South-South, Nigeria from 2010 - 2019, in terms of catchment area criterion, showed an upward trend. Reasons for this may be because Cross River, Rivers and Bayelsa are the only states considered as educationally less developed in southsouth, Nigeria. As such, admission slots are reserved for indigenes of the southsouth region which usually has a large number of candidates seeking admission into universities within their catchment area. This finding aligns with the views of Akpan (19900) that the effect of catchment criterion has been calamitous, admitting candidates on merit have a tendency to be undermined, thus allowing less competent candidates to be given admission. This also agrees with Omeje et al. (2016) who argued that catchment area criterion inspires social discernment of one group against the other. A Pattern of choosing certain candidates on the grounds of the state of birth and the tribe to the detriment of others in the course of higher education.

\section{CONCLUSION}

Based on the findings of this study, it was concluded that, there is an upward pattern witnessed in the enrolment in federal universities in southsouth, Nigeria from 2010 - 2019. Conclusively, there is an upward pattern in enrolment over the years. However, this upward pattern is not commensurate with the growth in population and the desire to acquire university education among Nigerians. This upward trend in enrolment does not necessarily mean that enrolment is increasing when compared to those who sought admission yearly. Going by the current enrolment trend, the University of Calabar has been forecasted to admit more students into her academic programmes in the future (2020 to 2031) than the University of Benin and University of Uyo respectively, based on gender, merit and catchment enrolment criteria. In the future, enrolment across federal universities will continually increase at the aggregate level but not at the institutional level. At the institutional level, the University of Calabar will consistently record upward linear-moving patterns in her enrolment in terms of the merit and catchment criteria; while there will be enrolment fluctuations in the University of Benin and the University Uyo respectively. At the aggregate level, more females are likely to be enrolled in academic programmes in federal universities than males; while at the institutional level, enrolment will fluctuate based on gender.

\section{RECOMMENDATIONS}

It was based on the conclusion of the research that the researchers made the following recommendations:

1. Equal university admission slots should be made available to both male and female admission seekers through national legislation. A total war should also be declared on gender discrimination.

2. To ensure that a significant number of candidates are admitted on merit, government, private investors, TETFund and other stakeholders be encouraged to sponsor more infrastructural projects in universities to provide the required infrastructure to accommodate more candidates seeking for placement in the universities.

3. To ensure the simplification of admission and features of openness to a mixed population, the catchment area criterion which placed some states at a privileged situation over others regardless of the school-going population ought to be reviewed by the interested partied and educational institutions. The government should take adequate measures to eradicate indigene/non-indigene politics in the admission process.

Conflicts of Interest: The authors declare no conflict of interest. 
Acknowledgments: The researchers are grateful to the research assistants who assisted in the data collection process. We also wish to aknowledge the efforts of the professionals who validated the instrument used for data collection.

Disclaimer Statement: Not applicable to this study

\section{Notes on Authors:}

Valentine Joseph Owan is a research scholar in the Department of Educational Management, University of Calabar, Nigeria. His research interest cut across Educational Leadership, Item Response Theory, Research, Measurement and Evaluation. He is widely published in both International and the Nigerian Literature. $\mathrm{He}$ is currently a member of the Nigerian Association for Educational Administration and Planning (NAEAP) and the Common-Wealth Council of Educational Administration and Management (CCEAM) in Africa.

Dr. Eyiene Ameh is a lecturer in the Department of Educational Management, University of Calabar, Calabar. His research interest is in Educational Management and holds a PhD in Economics and Politics of Education. He is a member of Nigerian Association for Educational Administration and Planning.

Mary Chinelo Ubabudu is an Associate Professor in the Department of Business Administration, Nigerian Air Force Institute of Technology (AFIT), Kaduna. Her research areas include Human Resources, Strategic Management, Educational Management, International Relations and Diplomacy. She has many scholarly publications to her credit. Dr. Ubabudu is a member of the Nigerian institute of Management (NIM, Chartered); International Academy of Business and Public Administration Disciplines (IABPAD), USA; Nigerian Association for Educational Administration and planning (NAEAP) to mention a few.

\section{Authorship and Level of Contribution:} Valentine Joseph Owan was instrumental in identifying the problem, building the background, literature review, design, data collection, instrument design and data collection and analysis, discussion of findings, editing and approving the manuscript. Ameh Eyiene was responsible in drafting the manuscript, drafting the methodology, design of the instrument, collection of data, editing and approving the manuscript. Mary Chinelo Ubabudu participated in the data collection, data cleaning and curation, editing and approving the manuscript of the article.

\section{REFERENCES}

Adeyemi, J. K., \& Akpotu, N. (2004). Gender analysis of student enrolment in Nigerian universities. Higher Education, 48(3), 361 378.

https://doi.org/10.1023/B:HIGH.0 000035547.19318 .27$.

Adeyemi, K. (2001). Equity of access and catchment area factor in university admissions in Nigeria. Higher Education, 42(3), 307-332. https://doi.org/10.1023/A:101796 5905830.

Agboola, B. M., \& Ofoegbu, F. I. (2010). Access to university education in Nigeria: A review. A pre-print. https://bit.ly/3ifMNkm.

Agu, S. (2004). Gender equality, education and women empowerment: The Nigerian challenge. Multidisciplinary Journal of Research Development, 8(2), 1 - 7. http://bit.ly/3c7Auph.

Ahmed, U. B. (2010). Promoting the education of married adolescent girls in Northern Nigeria. Nigerian Academy of Education Year Book, 6, $191-206$.

Akpan, P. A. (1990). The role of higher education in national integration in Nigeria. Higher Education, 19(3), 293-305. https://doi.org/10.1007/BF00133 894.

Akpotu, N. E. (2005). Deregulating the Nigerian university system: Implications for equity and access. In G. O. Akpa, S. U. Udoh, \& E. O. Fagbamiye (Eds), Deregulating the provision and management of 
education in Nigeria. Nigerian Association of Educational Administration and Planning (NAEAP), pp.57-62.

Chibuogwu, V. N. (2016). Factors influencing the enrolment of women into higher education programmes at the National Open University of Nigeria. Journal of Educational Research and Behavioural Sciences, 5(3), 041045. https://bit.ly/2KHDYDy.

Dokubo, I. N., \& Deebom, M. T. (2017). Gender disparity towards students' enrolment in technical education in Rivers State: Cause, effects and strategies. International Journal of ResearchGranthaalayah, 5(10), 1-10. https://doi.org/10.29121/grantha alayah.v5.i10.2017.2260.

Ekaette, S. O., Ekpenyong, J. A., \& Owan, V. J. (2019). School characteristics and enrollment trend in upper basic schools in Akwa Ibom State, Nigeria from 2008-2016. Pedagogical Research, 4(3), em0039. https://doi.org/10.29333/pr/5855

Ekaette, S. O., Owan, V. J., \& Agbo, D. I. (2019). External debts and the financing of education in Nigeria from 1988 - 2018: Implication for effective educational management. Journal of Educational Realities (JERA), 9(1), $1-14$.

https://doi.org/10.5281/zenodo.4 320606.

Esomonu, N. P. M., \& Adirika, B. N. (2012). Assessment of access to university education in Nigeria. Research Journal in Organizational Psychology \& Educational Studies, 1(5), 303-306.

https://bit.ly/368IfZz.

Federal Ministry of Education (2009). Roadmap for the Nigerian education sector. Ministry of Education Publications. https://bit.ly/3cagG4y.

Ibrahim, B. B., \& Ahmed, U. M. (2012). Access to university education: Perceived problems militating against admission into Nigerian universities. Interdisciplinary Journal of Contemporary Research in Business, 4(6), 244-254. https://bit.ly/3iI031m

JAMB Registration Statistics (2019). Statistical reports on UTME applications: Over 1.6 million candidates for 2019 UTME. https://nigerianscholars.com/scho ol-news/jamb-registrationstatistics/

Mbon, U. F., Omorobi, G. O., Owan, V. J., \& Ekpenyong, J. A. (2019). Analysis of the quality of educational resources and effective instructional service delivery in Nigerian Universities. International Journal of Education and Evaluation, 5(7), 2534.

https://doi.org/10.5281/zenodo.445 8688.

Nwajiuba, C. A. (2011). Culture and sex imbalance in higher education in Nigeria: Implications for development. Educational Research, 2(3), 926-930. https://bit.ly/3c6isUd.

Obasi, K. K., \& Ohia, A. N. (2015). The criteria for admission into the Nigerian universities and the quality of the graduates in South East, Nigeria. Nigerian Journal of Educational Administration and Planning, 15(2), 385-396.

Odigwe, F. N., \& Owan, V. J. (2019). Trend analysis of the Nigerian budgetary allocation to the education sector from 2009 2018 with Reference to UNESCO'S $26 \%$ Benchmark. International Journal of Educational Benchmark, 14(1), 1-14. https://bit.ly/2z5nZJA.

Ojerinde, D. (2011). Contemporary educational issues in Nigeria. Melrose Books and Publishing Ltd.

Okeke, F. N., \& Isiozo, G. N. (2013). Effective management of university admission processes as a panacea to inequality access by candidates in Imo State University. Journal of Educational Review, 6(3), 379-383. 
Okoroma, N. S. (2008). Admission policies and the quality of university education in Nigeria. Educational Research Quarterly, 31(3), $13-24$ https://bit.ly/2LZqd3Q.

Omeje, J. C., Egwa, E. I., \& Adikwu, V. O. (2016). Impact of quota system and catchment area policy on the university admissions in North Central, Nigeria. SAGE Open.

https://doi.org/10.1177/2158244 016654951.

Oyebade, S. A. (2008). Gender participation in university education in Nigeria and some commonwealth countries. https://nigeriaworld.com/articles/ html.

Ukertor, G. M. (2010). The challenges of access to university education in Nigeria. DSM Business Review, 2(1), 35-39.

Uwakwe, C., Ajibola, F. Benedicta, E. \& Omobola, A. (2008). Impact of decentralization and privatization on the quality of education in SubSahara Africa: The Nigeria experience. European Journal of Social Science, 7(1), 34-38. https://bit.ly/2YcU0Z6. 